\title{
Unit of International System of Units
}

National Cancer Institute

\section{Source}

National Cancer Institute. Unit of International System of Units. NCI Thesaurus. Code C42532.

A base or derived unit of weight or measure that belongs to the decimal International System of Units (Systeme International d'Unites, SI) derived from and extending the metric system. 